\title{
Natural products in the predatory defence of the filamentous fungal pathogen Aspergillus fumigatus
}

\author{
Jana M. Boysen ${ }^{\ddagger 1,2}$, Nauman Saeed $\$ 1,2$ and Falk Hillmann ${ }^{* 1}$
}

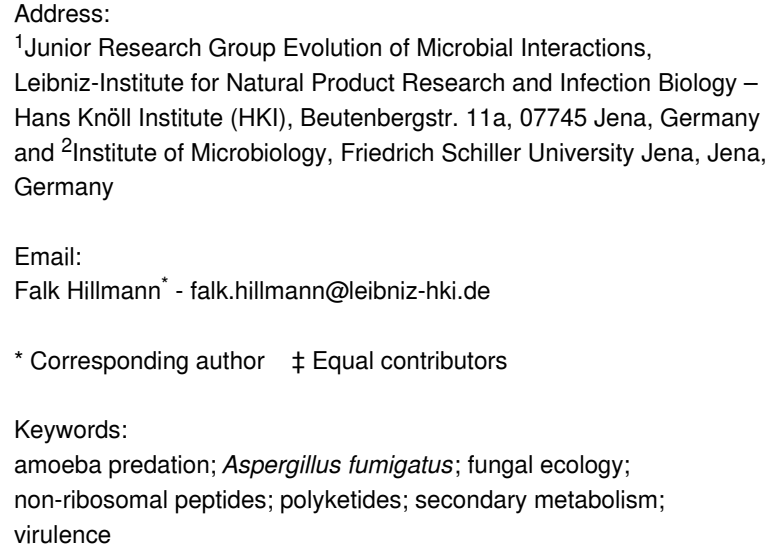

Beilstein J. Org. Chem. 2021, 17, 1814-1827. https://doi.org/10.3762/bjoc.17.124

Received: 15 January 2021

Accepted: 14 July 2021

Published: 28 July 2021

This article is part of the thematic issue "Chemical ecology".

Guest Editor: C. Beemelmanns

(C) 2021 Boysen et al.; licensee Beilstein-Institut. License and terms: see end of document.

\begin{abstract}
The kingdom of fungi comprises a large and highly diverse group of organisms that thrive in diverse natural environments. One factor to successfully confront challenges in their natural habitats is the capability to synthesize defensive secondary metabolites. The genetic potential for the production of secondary metabolites in fungi is high and numerous potential secondary metabolite gene clusters have been identified in sequenced fungal genomes. Their production may well be regulated by specific ecological conditions, such as the presence of microbial competitors, symbionts or predators. Here we exemplarily summarize our current knowledge on identified secondary metabolites of the pathogenic fungus Aspergillus fumigatus and their defensive function against (microbial) predators.
\end{abstract}

\section{Introduction}

To thrive in their natural habitats all organisms from bacteria and fungi to plants and animals need access to sufficient nutritional sources and have to defend themselves against both, competitors and predators (Figure 1). Fungi are ubiquitous, living a mostly saprophytic, parasitic or symbiotic lifestyle in various habitats including soil, water, other organisms and even salt-flats and arctic glaciers [1,2]. As fungi are not able to phys- ically leave their habitats they must rely on mechanical barriers, physiological adaptations and chemical defence mechanisms to optimize their living conditions and resist competitors, parasites and predators [3-5]. These bioactive compounds are often considered as secondary metabolites (SM) which are involved in communication, symbiotic interactions, pathogenicity or chemical defence, e.g., by toxin production [6]. With penicillin 


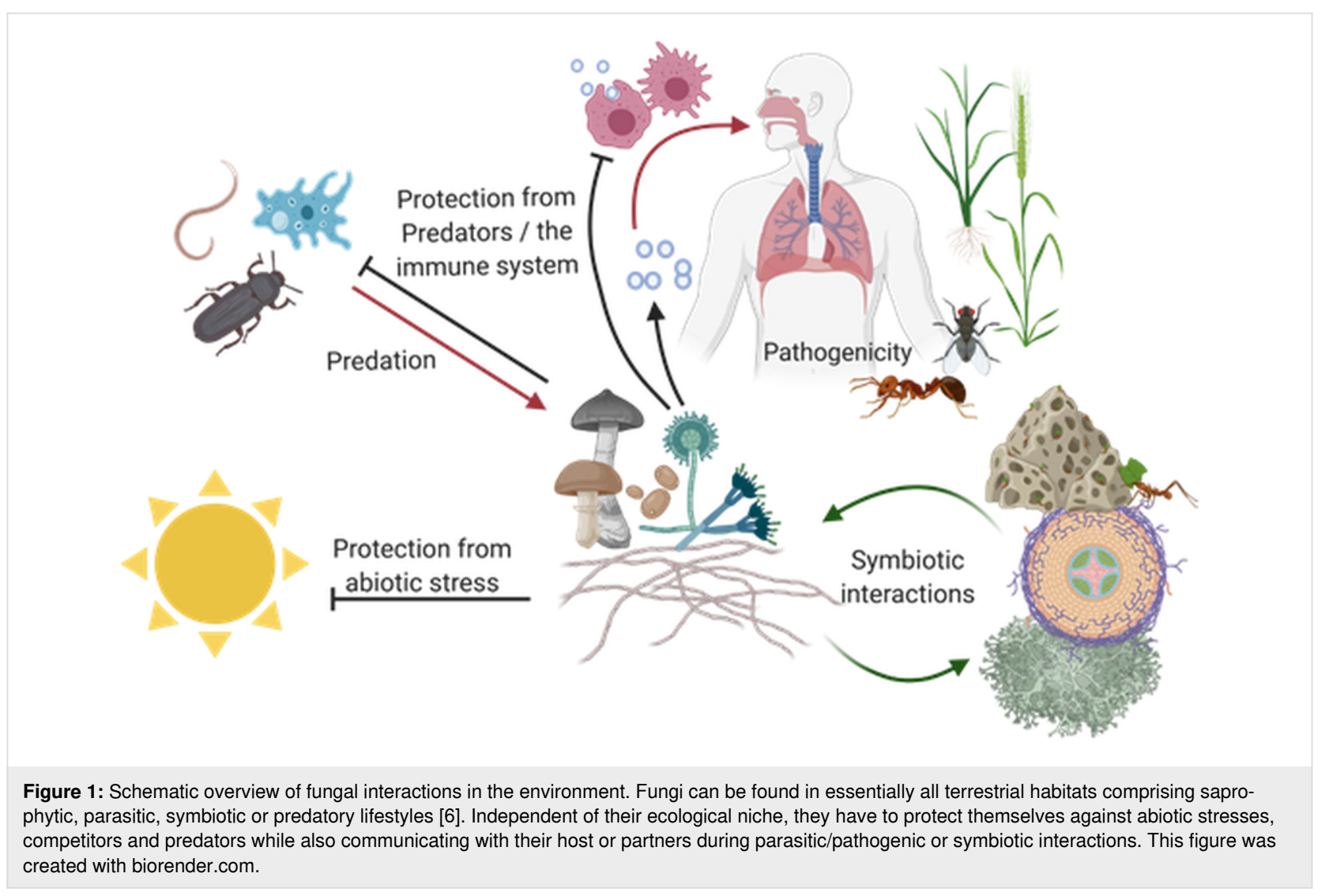

as the prime example fungal secondary metabolites have raised scientific and pharmaceutical interests for nearly one century. Today's sequencing and bioinformatic analyses of fungal genomes revealed that the genetic potential far exceeds the number of known metabolites and the interest of scientists to gain access to them remains high [7-9].

Genes associated with these bioactive compounds are often organized in biosynthetic gene clusters (BGCs) which are physically linked, commonly regulated and often belong to a few distinct classes of molecules like non-ribosomal peptides (NRP), polyketides (PK), terpenes or indole alkaloids [10,11]. The vast majority of fungal BGCs is found in the genomes of members of the Basidiomycota and Ascomycota including the genus Penicillium in which the first BGC was identified in 1990 [12-14]. Penicillium species belong to the Pezizomycotina, a subdivision within the Ascomycotina including several species that are closely associated with humans at many different levels. Aside from being a source of many medically relevant compounds including antibiotics like penicillin they offer food sources in the form of naturally grown truffles (e.g., Tuber melanosporum) or recently cultivated meat alternatives like Quorn ${ }^{\circledR}$ (Fusarium venenatum) [15-17]. Species of Aspergillus, such as Aspergillus fumigatus, Aspergillus flavus and Aspergillus niger can affect the health of humans, plants and lifestock by acting as pathogens. It is firmly established that the ability to produce mycotoxins contributes to the virulence potential of these fungi, but as they all thrive in environmental reservoirs they must also provide an ecological advantage to their producer [18].

Indeed, many of these pathogenic fungi also produce compounds with antibacterial, antifungal and insecticidal properties to ward of both competitors and predators. The mycotoxins aflatoxin B1 (1) from Aspergillus flavus and patulin (2), produced by Aspergillus and Penicillium species, exhibit insecticidal activity against Drosophila melanogaster and might thus prevent feeding competition [19-21] (Figure 2). But not only mycotoxins protect from predation: A. flavus sclerotia are protected from sap beetles by asparasone and Neurospora crassa's neurosporin A prevents springtail grazing [22,23]. Grazing by Folsomia candida springtails on Fusarium graminearum induces several metabolites, of which especially the bisnaphthopyrone pigment aurofusarin (3) was shown to have antifeedant effects not only on springtails but also on mealworm Tenebrio molitor and woodlouse Trichorhina tomentosa. Not only Fusarium species produce bisnaphthopyrones like aurofusarin but also Aspergillus and Penicillium species produce these metabolites which show antifeedant effects on a wide variety of arthropods [24]. 


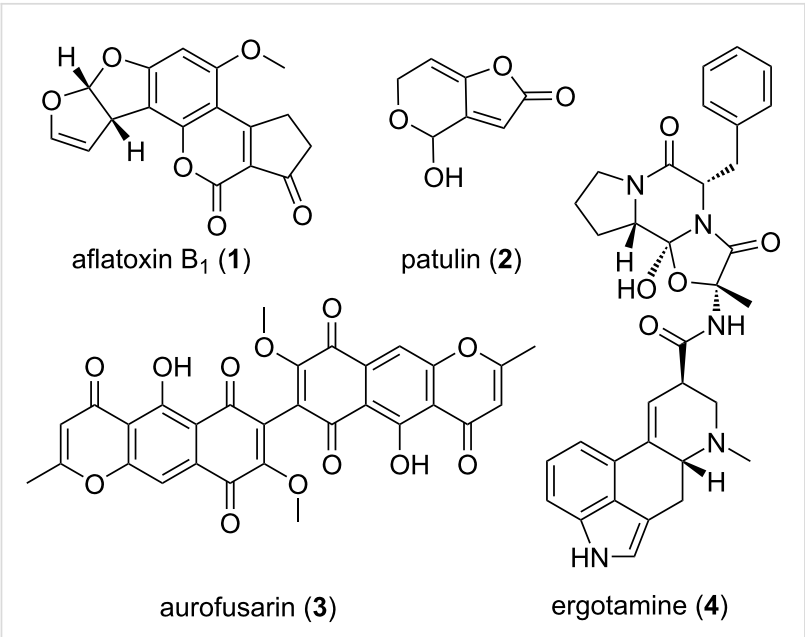

Figure 2: Fungal derived bioactive natural compounds with ecological and/or economic relevance.

Some fungal compounds can have deleterious effects on humans, livestock or crops, like the ergot alkaloids, e.g., ergotamine (4) present in the sclerotia of the ergot fungus Claviceps purpurea, which can contaminate grain products like flour. In the middle ages these contaminations caused vast epidemics of "St. Anthony's fire", a severe poisoning which could lead to death and mutilation in humans. However, midwives already knew the therapeutic potential of ergot alkaloids as early as 1582 and used it for abortion or to aid childbirth. The ecological significance of ergot alkaloids remains unclear, but they are assumed to be a feeding deterrent due to their toxicity and bad taste [25-28].

To trigger the synthesis of new SMs a number of approaches have been exploited so far, including co-cultivation with other species [9]. Amoebae offer promising possibilities to not only discover new SM but also to discover their ecological role as amoeba often cohabitate with fungi in their natural environments, especially the soil. Some, like Protostelium aurantium, were recently found to be exclusively fungivorous, feeding on both yeasts and filamentous fungi alike [29]. Additionally, amoeba closely resemble human phagocytic cells and the interactions of fungi and amoeba often parallels interactions of fungi and macrophages as was shown for Aspergillus fumigatus and its interactions with Acanthamoeba castellanii [30]. Thus, the adaptations that protect fungi against amoeba that were gained in the 'environmental school of virulence' might also protect fungi from the immune system [31]. Therefore, to study their interactions with human pathogenic fungi like A. fumigatus, one of the most common airborne fungal pathogens, might lead to new insight in virulence mechanisms and the role of SMs therein [32]. The aim of this review is to depict the fungal secondary metabolite potential and its role in an ecological context using A. fumigatus as an example because of its high medical importance and its diverse profile of secondary metabolites which seems to fulfil dual roles: targeting innate immune cells during virulence and protect from environmental predators in natural habitats.

\section{Review}

\section{Natural products of Aspergillus fumigatus}

The genus Aspergillus comprises a large number of species that are not only of scientific but also of pharmaceutical and commercial interest. While the non-pathogenic A. niger is used as industrial workhorse, for example in the production of citric acid, other representatives contaminate food stocks with mycotoxins (A. flavus) or can cause severe infections (A. fumigatus, A. terreus). Despite their different role for humans, they commonly share a high potential for the production of secondary metabolites, measured by the predicted number of secondary metabolite gene clusters identified by numerous genome sequencing projects. Due to its clinical importance as an opportunistic pathogen A. fumigatus is of great interest among them $[33,34]$.

As a saprophytic decomposer of organic material in the soil, A. fumigatus encounters not only numerous competitors but also fungivorous predators like amoebae (e.g., P. aurantium), nematodes (e.g., Aphelenchus avenae) or arthropods like insects, mites and springtails (e.g., F. candida) [35-39]. However, the fungus may also act as a pathogen causing often lethal infections in immune-compromised patients, and thus its secondary metabolism was extensively studied in recent years [38,40,41]. Analysis of the A. fumigatus genome sequence and metabolomics revealed its potential to synthesize more than 200 compounds and the presence of over 30 secondary metabolite associated gene clusters [7,42-44]. The products of many of those gene clusters are already known and span the whole range of secondary metabolite classes. Table 1 provides an overview of the major secondary metabolites from A. fumigatus and lists their ecological roles as well as their impact on virulence.

\section{Gliotoxin}

Gliotoxin $(\mathrm{GT}, \mathbf{5})$ is the non-ribosomal peptide (NRP) derived epipolythiodioxopiperazine (ETP's) class toxin of several fungal genera including Aspergillus, Penicillium, Trichoderma, and Leptosphaera (Figure 3) [112]. Among the ascomycetes, A. fumigatus may well be the major GT producer and the identification of its heterocyclic structure by Bell and colleagues in 1958 builds the foundation to understand its role in invasive aspergillosis [113]. In A. fumigatus 13 genes form a $28 \mathrm{~kb}$ biosynthetic cluster of gliotoxin, of which gliZ (a zinc-finger transcription factor) and gliP (an NRPS) together with global regulator LaeA regulate its expression at the genomic level 
Table 1: Overview of Aspergillus fumigatus secondary metabolites and their roles during virulence and in their ecological context.

\begin{tabular}{|c|c|c|c|c|c|}
\hline Metabolite & Class & $\begin{array}{l}\text { Virulence } \\
\text { factor }\end{array}$ & Role in virulence & $\begin{array}{l}\text { Ecological role/ } \\
\text { toxicity }\end{array}$ & Reference \\
\hline DHN-melanin & $\begin{array}{l}\text { polyketide, phenolic } \\
\text { polymer, pigment }\end{array}$ & yes & $\begin{array}{l}\text { - prevents recognition by } \\
\text { the immune system } \\
\text { - prevents phagosomal } \\
\text { acidification }\end{array}$ & $\begin{array}{l}\text { - protection against } \\
\text { UV-stress } \\
\text { - prevents } \\
\text { recognition by } \\
\text { predators (e.g., } \\
\text { amoeba) } \\
\text { - prevents } \\
\text { phagolysosome } \\
\text { maturation }\end{array}$ & {$[45-50]$} \\
\hline endocrocin & polyketide, pigment & - & $\begin{array}{l}\text { - inhibits chemotaxis of } \\
\text { neutrophils }\end{array}$ & $\begin{array}{l}\text { - protection against } \\
\text { UV-stress }\end{array}$ & {$[47,51-53]$} \\
\hline ferricrocin & siderophore & yes & - iron homeostasis & - iron homeostasis & {$[54,55]$} \\
\hline fumagillin & mero-terpenoid & - & $\begin{array}{l}\text { - inhibitor of phagocyte } \\
\text { activity } \\
\text { - damages epithelial cells } \\
\text { - inhibitor of methionine } \\
\text { aminopeptidase }\end{array}$ & $\begin{array}{l}\text { - cilioinhibitory } \\
\text { - antimicrobial } \\
\text { - antiprotozoal }\end{array}$ & {$[56-62]$} \\
\hline fumigaclavine & ergot alkaloid & - & $\begin{array}{l}\text { - reduces production of } \\
\text { TNF- } \alpha \text { - toxic to } \\
\text { mammalian cells }\end{array}$ & $\begin{array}{l}\text { - antibacterial } \\
\text { - insecticidal } \\
\text { - antifeedant }\end{array}$ & {$[63-67]$} \\
\hline fumipyrrole & non-ribosomal peptide & - & - & $\begin{array}{l}\text { - enhances growth } \\
\text { and sporulation }\end{array}$ & [68] \\
\hline fumiquinozalines & $\begin{array}{l}\text { tryptophan derived peptidyl } \\
\text { alkaloid }\end{array}$ & - & not determined & $\begin{array}{l}\text { - antibacterial } \\
\text { - antifungal }\end{array}$ & {$[69-72]$} \\
\hline fumisoquin & isoquinolone alkaloid & - & not determined & $\begin{array}{l}\text { - inhibits bacterial } \\
\text { replication }\end{array}$ & {$[73,74]$} \\
\hline fumitremorgin & $\begin{array}{l}\text { indole diketo-piperazine } \\
\text { alkaloid }\end{array}$ & - & $\begin{array}{l}\text { - inhibitor of breast cancer } \\
\text { resistance protein }\end{array}$ & $\begin{array}{l}\text { - antifungal } \\
\text { - antifeedant } \\
\text { - insecticidal }\end{array}$ & {$[72,75]$} \\
\hline $\begin{array}{l}\text { fusarinine } \mathrm{C} / \\
\text { triacetylfusarinine } \mathrm{C}\end{array}$ & siderophore & yes & - iron acquisition & - iron acquisition & {$[54,55,76]$} \\
\hline fungisporin & non-ribosomal peptide & - & not determined & - antibacterial & {$[41,77]$} \\
\hline gliotoxin & epipolythiopiperazine & yes & $\begin{array}{l}\text { - inhibition of immune } \\
\text { response }\end{array}$ & $\begin{array}{l}\text { - cilioinhibitory } \\
\text { - antimicrobial } \\
\text { - protects against } \\
\text { amoeba predation }\end{array}$ & [78-82] \\
\hline $\begin{array}{l}\text { helvolic acid/ } \\
\text { protostadienol }\end{array}$ & fusidane-type steroid & - & - cilioinhibitory & $\begin{array}{l}\text { - antibacterial } \\
\text { - antiprotozoal } \\
\text { - antifungal }\end{array}$ & {$[72,83-88]$} \\
\hline $\begin{array}{l}\text { hexadehydro- } \\
\text { astechrome }\end{array}$ & $\begin{array}{l}\text { non-ribosomal peptide, } \\
\text { tryptophan-derived iron(III) } \\
\text { complex }\end{array}$ & yes & - iron homeostasis & - iron homeostasis & {$[89,90]$} \\
\hline $\begin{array}{l}\text { neosartoricin/ } \\
\text { fumicycline }\end{array}$ & $\begin{array}{l}\text { prenylated polyketide, } \\
\text { meroterpenoid }\end{array}$ & - & $\begin{array}{l}\text { - inhibition of immune } \\
\text { response }\end{array}$ & not determined & {$[41,91,92]$} \\
\hline nidulanin $\mathrm{A}$ & $\begin{array}{l}\text { tetracyclo-peptide/ } \\
\text { isoprene }\end{array}$ & - & not determined & not determined & [93] \\
\hline pseurotin & heterocyclic $y$-lactam & - & $\begin{array}{l}\text { - inhibition of } \lg E \\
\text { production }\end{array}$ & - antibacterial & [94-97] \\
\hline pyripyropene A & sesqui-terpenoid & - & - acetyltransferase inhibitor & $\begin{array}{l}\text { - nematicide } \\
\text { - insecticidal }\end{array}$ & [98-100] \\
\hline sphingofungin $A-D$ & sphingosine-like compound & $\begin{array}{l}\text { not } \\
\text { determined }\end{array}$ & $\begin{array}{l}\text { - inhibition of serine } \\
\text { palmitoyl transferase }\end{array}$ & - antifungal & [101-104] \\
\hline trypacidin & $\begin{array}{l}\text { polyketide, anthraquinone, } \\
\text { pigment }\end{array}$ & - & - toxic to lung cells & $\begin{array}{l}\text { - antiprotozoal } \\
\text { - antiphagocytic }\end{array}$ & {$[53,105-107]$} \\
\hline verruculogen & $\begin{array}{l}\text { indole diketo-piperazine } \\
\text { alkaloid }\end{array}$ & $\begin{array}{l}\text { not } \\
\text { determined }\end{array}$ & $\begin{array}{l}\text { - alters electrophysical } \\
\text { properties of human nasal } \\
\text { epithelial cells }\end{array}$ & - antifungal & {$[72,108-110]$} \\
\hline
\end{tabular}


Table 1: Overview of Aspergillus fumigatus secondary metabolites and their roles during virulence and in their ecological context. (continued)

xanthocillin

tyrosine-derived isocyanide -

- copper homeostasis - copper

homeostasis

[111]

[112,114-116] (Figure 3). Whereas GliT (a gliotoxin oxidoreductase) catalyses the oxidation of reactive dithiol gliotoxin (6) to gliotoxin and a distantly localized $S$-adenosylmethioninedependent gliotoxin bisthiomethyltransferase $(\mathrm{Gtm} A)$ is responsible for the formation of bis(methyl)gliotoxin (7) to maintain the GT concentration at sub-lethal levels via redox cycling and S-methylation of active disulfides in GT, respectively $[117,118]$. Furthermore, in terms of exogenous factors, not only GT itself but several other biotic and abiotic factors, including neutrophilic granulocytes, media composition, $\mathrm{pH}$, temperature and aeration, are known to regulate gliotoxin biosynthesis $[115,119,120]$.

The biological activity of ETP's like gliotoxin is mediated by the active disulfide bridge that targets vulnerable thiols or catalyses oxidative burst formation via redox cycling [78]. In previous studies, these cytotoxic activities of gliotoxin were shown to be immunosuppressive in humans [79-81]. Sugui and colleagues (2007) also demonstrated that a gliotoxin lacking strain of A. fumigatus is avirulent in mice treated with cortisone acetate [121]. Nevertheless, the fact that gliotoxin is not only produced by pathogenic A. fumigatus suggests a role of gliotoxin in natural microenvironments. In vitro studies have also revealed the amoebicidal activities of gliotoxin on its natural co-inhabitant Dictyostelium discoideum [82]. However, these pathogenic activities sometimes prove to be beneficial for other co-habitants, comparable to how Trichoderma virens protects cotton seedlings from its pathogen Pythium ultimum [122].

\section{Trypacidin}

The spore-born toxin trypacidin $(\mathbf{8})$ is a polyketide that belongs to an anthraquinone-derived class of secondary metabolites (Figure 4) [107]. In A. fumigatus, the trypacidin biosynthetic cluster $(t p c)$ is comprised of 13 genes that spans over a $25 \mathrm{~kb}$ sub-telomeric region on chromosome $4[53,105]$. It is one of the conidial secondary metabolites that are regulated by global transcriptional regulators LaeA and BrlA in A. fumigatus [51,123126]. Nevertheless, trypacidin production is also regulated by cluster specific transcriptional regulators TpcD/E [53]. Though the precise mechanism of action of trypacidin remains to be elucidated, it was shown to exhibit antiprotozoal, antiphagocytic and cytotoxic activities in vitro. Gauthier and colleagues (2012) have shown that in lung cells trypacidin mediates in necrosismediated death [107]. In another study, absence of trypacidin was shown to be linked with increased phagocytic rates in murine alveolar macrophages and phagocytic amoeba D. discoideum. The authors further showed that trypacidin reduced the viability of amoebae which signifies its role in conidial protection in the environment [105].

\section{Fumagillin}

Fumagillin (9) belongs to the meroterpenoid class of secondary metabolites. It was discovered in 1949 from A. fumigatus [127].

\section{8 kb}

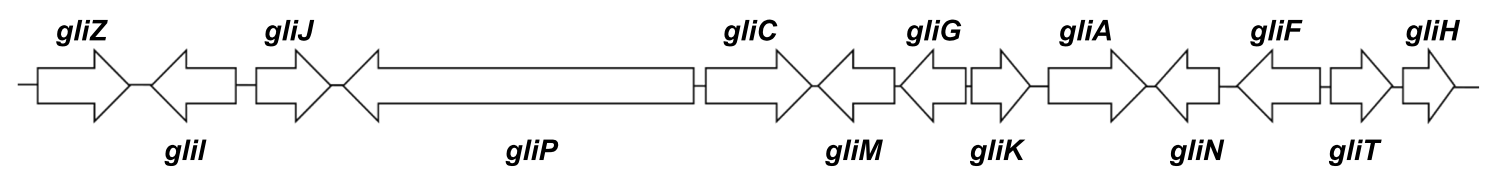<smiles>CN1C(=O)C2CC3=CC=CC(O)C34NC(=O)C(CO)(S4)[N+]21C</smiles>

gliotoxin (5)

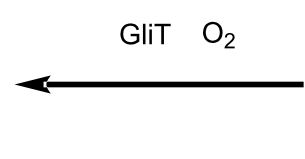

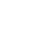

Figure 3: Gliotoxin biosynthetic gene cluster and it major biosynthetic transformations: Gliotoxin (5) is the oxidized form of dithiol-gliotoxin (6) catalysed by the gliotoxin oxidoreductase GliT. Dithiol-gliotoxin can be methylated to bis(methyl)gliotoxin (7) via the S-adenosyl-methionine (SAM) dependent bisthiomethyltransferase GtmA which is not part of the gli-cluster. 
<smiles>C=C(C)C1=CC(=O)C=C(OC)C12Oc1cc(C)cc(OC)c1C2=O</smiles>

trypacidin (8)

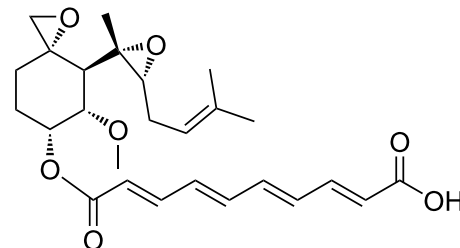

fumagillin (9)
Figure 4: Amoebicidal secondary metabolites trypacidin and fumagillin of Aspergillus fumigatus.

Strikingly, unlike other secondary metabolite synthesizing clusters, the fumagillin biosynthetic cluster is intertwined with the pseurotin gene cluster and designated as the fma cluster [95,128]. Wiemann and colleagues (2013) have shown the existence of a similarly intertwined pattern in both close and distant relatives of A. fumigatus, and therefore suggested a role of these metabolites in survival. In A. fumigatus, the fma cluster is located on the sub-telomeric region on chromosome 8 and is comprised of 15 genes. At the cellular level fumagillin is regulated by both cluster specific regulator FumR (FapR) and global regulator LaeA [95].

Fumagillin consists of a cyclohexane ring and decatetraenedioic acid connected via an ester bond. There is also a methoxy group, an epoxide and a terpene derived aliphatic chain that contains another epoxide, linked to cyclohexane. These unstable di-epoxides are responsible for the biological activity of fumagillin, which targets the active site of the methionine aminopeptidase type-2 (MetAP-2) enzyme [129]. MetAP-2 is involved in cell proliferation, translation and post-translational modifications of nascent polypeptides and is therefore essential for cell viability $[130,131]$. Additionally, fumagillin is also known to be overproduced upon caspofungin treatment and damage to the cell walls while fumagillin aids in immune evasion by reducing
ROS levels, degranulation and actin filamentation in neutrophils $[60,132]$. In nature, several fungal species are known to produce caspofungin which could trigger fumagillin production in natural environments $[132,133]$. A. fumigatus possesses an additional MetAP-2 gene in the fma cluster that protects itself against its own toxin [134]. Fumagillin has therapeutic potential for the treatment of intestinal microsporidiosis and nosemiasis in honey bees $[58,135]$. Overall, antibiotic, immunosuppressive, antitumor and antiangiogenic properties have been attributed to fumagillin [129,136-140]. Specific antibiotic activities were demonstrated against the pathogen Entamoeba histolytica and later against eukaryotic parasites such as Trypanosoma and Plasmodium the causative agent of malaria [141,142]. In comparison to gliotoxin, we found only minor cytotoxic activities of fumagillin against the model amoebae D. discoideum [82]. It could still be conceivable that other amoeba could reveal higher sensitivity, but tests against the fungivorous amoeba $P$. aurantium were not yet conducted.

\section{DHN-melanin}

Melanins are a heterogenous group of hydrophobic phenolic polymers that are found in a range of organisms including bacteria, plants, fungi and even animals. The melanin pigments are of mostly dark colours like black or brown and are associated with virulence in plant- and animal-pathogenic fungi [143145]. Three types of melanins are known to be produced by fungi of which A. fumigatus is able to produce two - pyomelanin and dihydroxynaphthalene melanin (DHN-melanin). While the water-soluble pyomelanin is synthesized via the tyrosine degradation pathway, the DHN-melanin synthesis relies on its own SM-gene-cluster [146-148]. The DHN-melanin of A. fumigatus is a heteropolymer formed through the polymerization of 1,8-dihydroxynaphtalene (1,8-DHN) monomers (10) and is responsible for the unique greyish-green colour of A. fumigatus conidia (Figure 5).

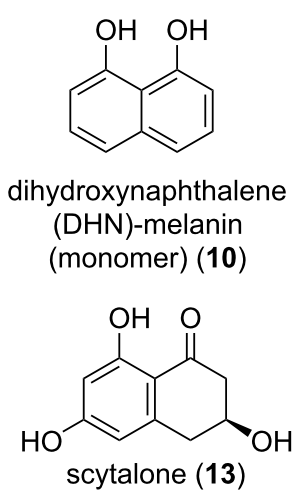

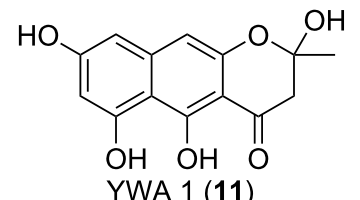<smiles>Oc1cc(O)c2c(O)cccc2c1</smiles>

1,3,8- trihydroxynaphthalene (14)<smiles>Oc1cc(O)c2c(O)cc(O)cc2c1</smiles><smiles>O=C1CC(O)Cc2cccc(O)c21</smiles> 
The genetics and biochemistry of its biosynthesis are well established: the $19 \mathrm{~kb}$ gene cluster contains 6 genes and lies downstream of the conidiation pathway. The polyketide synthase PksP combines the starter units acetyl-CoA and malonyl-CoA into the heptaketide naphthopyrone YWA1 (11) The hydrolytic activity of Ayg1 shortens the heptaketide to the pentaketide 1,3,6,8-tetrahydroxynaphthalene (1,3,6,8-THN) (12) and is further reduced by reductase Arp2 to scytalone (13), which in turn is dehydrated by Arp1 to 1,3,8-trihydroxynaphthalene (1,3,8-THN) (14). Again, Arp2 reduces 1,3,8-THN to vermelone (15) before it is dehydrated to 1,8-dihydroxynaphthalene (1,8-DHN) (10) by Abr1, a multi-copper reductase. In a last step polymerization of 1,8 -DHN monomers is facilitated by the laccase Abr2 [45,149-152]. Knock out mutants of either ayg 1, arp2, or $a b r 2$ lead to different coloured conidia while loss of $p k s P$ aborts DHN-melanin synthesis completely which leads to white spores [45]. DHN-melanin is a heterogeneous polymer, as such it does not have a unique structure. Its insolubility aggravates any structural analyses of the deciphering of repetitive motives. However, there were studies doing either computational predictions or artificial oxidative polymerization studies of 1,8-DHN monomers [144,153].

Next to offering the conidia protection from UV radiation, DHN-melanin was shown to be a key factor to survival during both predation and virulence. When preyed upon by fungivorous amoeba like $P$. aurantium melanised conidia where not only internalized less than $\Delta p k s P$ conidia but were also able to prevent maturation of phagolysosomes [50,147]. During infection DHN-melanin masks the pathogen-associated molecular patterns on the spore-surface and is thus less likely to be recognized by the immune system. The $\Delta p k s P$ strain lacks this protection and is more easily recognized by the immune system, thus triggering a stronger immune response, including a higher pro-inflammatory response and increased recognition and ingestion by phagocytes rendering the $\Delta p k s P$ strain less virulent. Additionally, melanised conidia are more likely to survive internalization by lung epithelial cells $[147,154,155]$. Although DHNmelanin is generally associated with immune evasion it was recently found to be recognized in higher animals via the C-type lectin receptor (MelLec) which interacts with the naphthalenediol domain of DHN-melanin. Additionally, the surfactant protein D (SP-D), a soluble C-type lectin receptor (CLR), is also able to recognise DHN-melanin and opsonize it to increase the immune response. However, MelLec receptors are only present on some endothelial and myeloid cells $[156,157]$.

\section{Fumigaclavines}

Fumigaclavine C (19) is a tryptophan-derived indole alkaloid which was so far only shown to be produced by A. fumigatus while other fumigaclavines can for example also be found in Penicillium ssp. (fumigaclavine A (18) and B (17)) [66,158]. In all fungi, alkaloid biosynthetic pathways share a common basis, starting with the prenylation of L-tryptophan to dimethylallyltryptophan (DMAT). During several steps DMAT is converted to chanoclavine-I aldehyde, the last mutual intermediate. Branching into different pathways after this intermediate is mainly due to differences in the function of EasA, the enzyme catalysing the next biosynthetic step. In A. fumigatus EasA acts as a reductase and after additional steps chanoclavine-I aldehyde is converted into festuclavine (16) (Figure 6). Festuclavine is then oxidized to fumigaclavine B (17) which in turn is acetylated to fumigaclavine A (18). Finally a reverse prenylation of fumigaclavine A leads to fumigaclavine $C$ (19), the final product of fumigaclavine biosynthesis [159]. Biosynthesis of the intermediate festuclavine as well as fumigaclavines $\mathrm{A}-\mathrm{C}$ is dependent on LaeA regulation [124].

Its numerous bioactive effects hold the potential for a pharmaceutical use since it was shown to be an effective inhibitor of tumor necrosis factor-alpha (TNF- $\alpha$ ) production by preventing the activation of TLR4 by lipopolysaccharide (LPS) and was thus proposed for potential use against atherosclerosis [67]. Furthermore fumigaclavine $\mathrm{C}$ has also proven effective against MCF-7 breast cancer cells by arresting the cell cycle and promoting apoptosis while showing no cytotoxicity against RAW 264.7 cells, thus demonstrating their selectivity [65,67]. Further, fumigaclavine was shown to exhibit antibacterial properties and to contribute to virulence in the model insect Galleria mellonella [66].

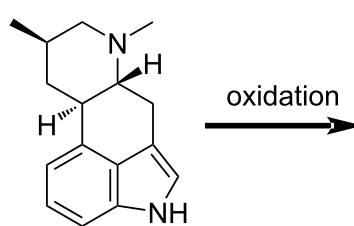

festuclavine (16)

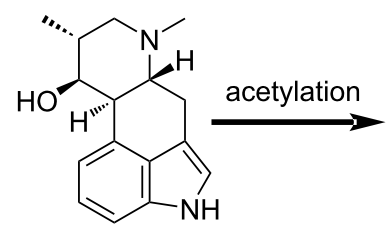

fumigaclavine $\mathrm{B}$ (17)

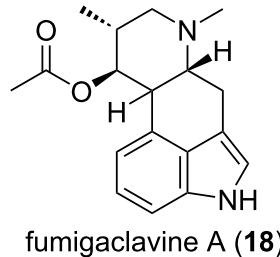

reverseprenylation

fumigaclavine A (18)

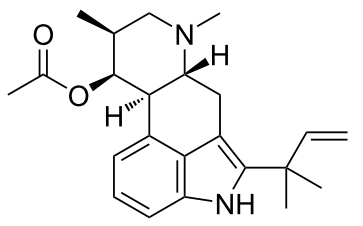

fumigaclavine $C$ (19) 


\section{Fumitremorgins}

The class of fumitremorgins comprises several diketopiperazine alkaloids which are tremorgenic mycotoxins. However, there are several fumitremorgin-like indole alkaloids including tryprostatins, spiro- and cyclotryprostatins and verruculogen besides fumitremorgins themselves. They occur most often in Aspergillus and Penicillium species [160]. Fumitremorgin A (20), B (21) and C (22) can all be found in A. fumigatus (Figure 7). They are based on the precursers L-tryptophan and L-proline and are further derived from breviamide F, proposedly via tryprostatin B which is hydroxylated and methylated to tryprostatin A. Oxidative closure of the ringstructure then results in fumitremorgin $\mathrm{C}$. Further modification of the structure leads to fumitremorgin B and verruculogen, which shares the same pathway [97,160-162]. Which enzyme is responsible for the conversion of verruculogen to fumitremorgin A remains to be elucidated. Like several other clusters, the biosynthesis of fumitremorgins is dependent on LaeA [124].

Fumitremorgin B was shown to have antifungal properties against phytopathogenic fungi, antifeedant properties against army-worm larvae and toxic on brine shrimp [72]. It was further shown to be cytotoxic and inhibiting cell cycle progression at G2/M phase [163]. Fumitremorgin $\mathrm{C}$ was shown to effect mammalian cells and inhibit the breast cancer resistance pro- tein which imparts multidrug resistance and thus resistance to chemotherapeutics in breast cancer treatment $[75,164]$.

\section{Helvolic acid}

Helvolic acid (HA) (23) is a fusidane-type antibiotic that belongs to the triterpenoid class of secondary metabolites. Originally, it was discovered from A. fumigatus but later several other members of the sub phylum Pezizomycotina were also found to be HA producers [165-168]. In A. fumigatus, the biosynthetic cluster of HA is comprised of 9 genes that spans over a $16.3 \mathrm{~kb}$ region on chromosome 4 (Figure 8). The cluster contains an oxidosqualine cyclase (helA), three Cytochrome P450 (helB1, helB2, helB3), a short-chain dehydrogenase/reductase (helC) and two acetyltransferases (helD1, helD2) and a 3 -ketosteroid- $\Delta^{1}$-dehydrogenase $[83,169]$. Helvolic acid is a tetracyclic compound containing two keto groups, two acetates and one carboxyl group which do not equally contribute to function [169]. Lv and colleagues have shown that the presence of both the C-20 carboxyl group and the 3-keto group are crucial for its antibacterial activity whereas, acetylation of the C-6 hydroxy group reduces the activity of HA [169]. Previous studies have also shown the antitrypanosomal, antifungal and cilioinhibitory properties of HA [72,83,86-88]. For these properties and little cross-resistance helvolic acid is of great pharmaceutical importance. On the other hand, these antibiotic activi-<smiles>COc1ccc2c3c4n(c2c1)[C@@H](C=C(C)C)OOC(C)(C)C[C@H]4N1C(=O)[C@@H]2CCCN2C(=O)[C@]1(O)[C@H]3OCC=C(C)C</smiles><smiles>COc1ccc2c3c(n(CC=C(C)C)c2c1)[C@@H](O)[C@@]1(O)C(=O)N2CCC[C@H]2C(=O)N1[C@H]3C=C(C)C</smiles>

fumitremorgin B (21)<smiles>COc1ccc2c3c([nH]c2c1)[C@@H](C=C(C)C)N1C(=O)C2CCCN2C(=O)[C@H]1C3</smiles>

fumitremorgin C (22)

fumitremorgin A (20)

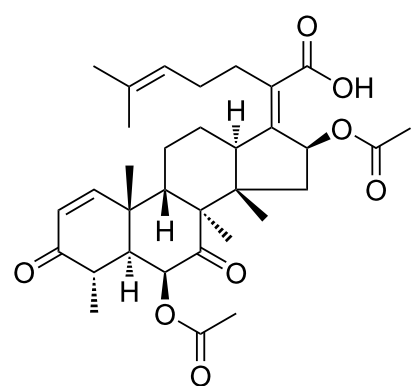

helvolic acid (23)

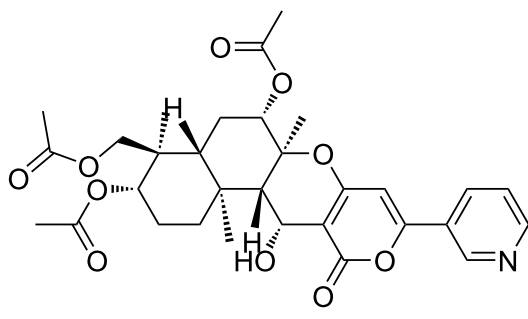

pyripyropene A (24) 


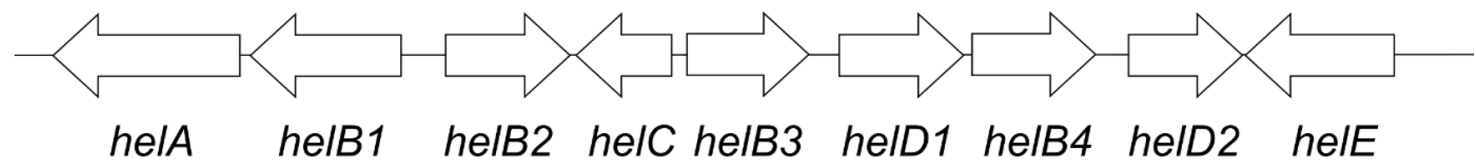

Figure 8: Helvolic acid gene cluster of $A$. fumigatus.

ties of HA could alter the soil microflora in natural habitats, an ecological role of HA that requires further investigation.

\section{Pyripyropene A}

Pyripyropene A (PPPA) (24) belongs to the meroterpenoid class of secondary metabolites. It was originally isolated from A. fumigatus, but later several other pyripyropene A producing members of Aspergillus and Penicillium ssp. were identified [98,99,170,171]. In A. fumigatus 9 genes form a pyripyropene A (pyr) biosynthetic cluster that spans a $23 \mathrm{~kb}$ region on chromosome 6 [172]. Chemically, pyripyropene (PP) analogs are meroterpenoids containing a fused pyridyl $\alpha$-pyrone moiety and eight contiguous stereocenters [170]. Metabolically, PPPA noncovalently binds within the fifth transmembrane domain of acyl-coenzyme A (CoA):cholesterol acyltransferase ACAT2 and renders it inactive [173]. In vivo, PPPA-mediated ACAT2 inhibition was shown to protect the mice from atherosclerosis, ACAT2 enzyme mediates in lipid metabolism and is localized in the liver and intestines [174]. Furthermore, PPPA was also shown to exhibit insecticidal properties against aphids [100].

\section{Conclusion}

Increasing access to sequenced microbial genomes offers a glimpse at the untapped potential we have yet to gain access to. Fungi in particular harbor great potential to produce novel secondary metabolites with ecological and pathogenic importance. As a medically relevant fungal pathogen A. fumigatus is the subject of much research and since sequencing of its genome in 2005 its potential for the production of secondary metabolites was scrutinized frequently $[7,43,175]$. In recent years many of its BGCs could be matched with either long known or newly discovered bioactive compounds and while the bioactive potential and the ecological role of many well studied metabolites like DHN-melanin or gliotoxin is well known, newer metabolites often cannot be associated with a biological function. Due to its clinical significance, the highest interest in secondary metabolites of A. fumigatus was driven by its pathobiology, e.g., a role in cytotoxicity, immunosuppression or antifungal drug resistance. In natural habitats these molecules may fulfill analogous functions, such as the defense against phagocytic predators by gliotoxin [78-82]. Indeed, the need for survival is the driving force of evolution and fungi like A. fumigatus were able to cultivate an impressive arsenal of protective mechanism from DHN-melanin which offers mostly passive protection to more active compounds like fumigaclavines or helvolic acid with their antibacterial and antifungal activities, respectively $[50,63,72,147]$. Since SM activities are most often closely related to ecological conditions mimicking of more natural cultivation conditions might lead to the discovery of new compounds and their ecological role.

In the past few years, protists like $D$. discoideum and Acanthamoeba castellani have been widely used for the identification of virulence attributes of pathogenic fungi, including Aspergillus spp., for their similarity with human phagocytic cells [32]. Nevertheless, the precise identity of amoeboid, nematode and arthropod predators that target filamentous fungi in their environmental niches remained elusive and has been limited by their biological complexity. It was thus surprising to find that the environmentally abundant, fungivorous amoeba $P$. aurantium does not only graze on yeast but can specifically target filamentous fungi such as A. fumigatus. The mechanism of action was coined ruphocytosis and involved a locally distinct disruption of the cell wall of the fungal hyphae to feed on the fungal cytoplasm [29]. It is well conceivable that this amoeba will target a range of different filamentous fungi, and that this biotic cell wall stress can be exploited as an ecological trigger for the production and identification of new bioactive compounds in the future.

\section{Funding}

Work in the authors' lab was supported by the Deutsche Forschungsgemeinschaft (DFG, German Research Foundation) under Germany's Excellence Startegy - EXC 2051 - Project-ID 390713860 and the research grants DFG HI1574/2-1 und HI1574/4-1. The graphical abstract and Figure 1 were created with BioRender.com.

\section{ORCID ${ }^{\circledR}$ iDs}

Jana M. Boysen - https://orcid.org/0000-0001-5877-0006 Nauman Saeed - https://orcid.org/0000-0003-3627-7725 Falk Hillmann - https://orcid.org/0000-0002-5493-930X 


\section{References}

1. Blackwell, M. Am. J. Bot. 2011, 98, 426-438. doi:10.3732/ajb.1000298

2. Cantrell, S. A.; Dianese, J. C.; Fell, J.; Gunde-Cimerman, N.; Zalar, P Mycologia 2011, 103, 1161-1174. doi:10.3852/11-108

3. Sutherland, I. W. Trends Microbiol. 2001, 9, 222-227. doi:10.1016/s0966-842x(01)02012-1

4. Costa-Orlandi, C. B.; Sardi, J. C. O.; Pitangui, N. S.; de Oliveira, H. C.; Scorzoni, L.; Galeane, M. C.; Medina-Alarcón, K. P.; Melo, W.; Marcelino, M. Y.; Braz, J. D.; Fusco-Almeida, A. M.; Mendes-Giannini, M. J. S. J. Fungi 2017, 3. doi:10.3390/jof3020022

5. Kowalski, C. H.; Morelli, K. A.; Schultz, D.; Nadell, C. D.; Cramer, R. A. Proc. Natl. Acad. Sci. U. S. A. 2020, 117, 22473-22483. doi:10.1073/pnas.2003700117

6. Spiteller, P. Nat. Prod. Rep. 2015, 32, 971-993. doi:10.1039/c4np00166d

7. Nierman, W. C.; Pain, A.; Anderson, M. J.; Wortman, J. R.; Kim, H. S. Arroyo, J.; Berriman, M.; Abe, K.; Archer, D. B.; Bermejo, C.; Bennett, J.; Bowyer, P.; Chen, D.; Collins, M.; Coulsen, R.; Davies, R. Dyer, P. S.; Farman, M.; Fedorova, N.; Fedorova, N.; Feldblyum, T. V.; Fischer, R.; Fosker, N.; Fraser, A.; García, J. L.; García, M. J.; Goble, A.; Goldman, G. H.; Gomi, K.; Griffith-Jones, S.; Gwilliam, R.; Haas, B.; Haas, H.; Harris, D.; Horiuchi, H.; Huang, J.; Humphray, S.; Jiménez, J.; Keller, N.; Khouri, H.; Kitamoto, K.; Kobayashi, T.; Konzack, S.; Kulkarni, R.; Kumagai, T.; Lafton, A.; Latgé, J.-P.; Li, W.; Lord, A.; Lu, C.; Majoros, W. H.; May, G. S.; Miller, B. L.; Mohamoud, Y.; Molina, M.; Monod, M.; Mouyna, I.; Mulligan, S.; Murphy, L.; O'Neil, S.; Paulsen, I.; Peñalva, M. A.; Pertea, M.; Price, C.; Pritchard, B. L.; Quail, M. A.; Rabbinowitsch, E.; Rawlins, N.; Rajandream, M.-A.; Reichard, U.; Renauld, H.; Robson, G. D.; de Córdoba, S. R.; Rodríguez-Peña, J. M.; Ronning, C. M.; Rutter, S.; Salzberg, S. L.; Sanchez, M.; Sánchez-Ferrero, J. C.; Saunders, D.; Seeger, K.; Squares, R.; Squares, S.; Takeuchi, M.; Tekaia, F.; Turner, G.; de Aldana, C. R. V.; Weidman, J.; White, O.; Woodward, J.; Yu, J.-H.; Fraser, C.; Galagan, J. E.; Asai, K.; Machida, M.; Hall, N.; Barrell, B.; Denning, D. W. Nature 2005, 438, 1151-1156 doi:10.1038/nature04332

8. Khaldi, N.; Seifuddin, F. T.; Turner, G.; Haft, D.; Nierman, W. C. Wolfe, K. H.; Fedorova, N. D. Fungal Genet. Biol. 2010, 47, 736-741. doi:10.1016/j.fgb.2010.06.003

9. Brakhage, A. A.; Schroeckh, V. Fungal Genet. Biol. 2011, 48, 15-22. doi:10.1016/j.fgb.2010.04.004

10. Keller, N. P.; Turner, G.; Bennett, J. W. Nat. Rev. Microbiol. 2005, 3 937-947. doi:10.1038/nrmicro1286

11. Gacek, A.; Strauss, J. Appl. Microbiol. Biotechnol. 2012, 95 1389-1404. doi:10.1007/s00253-012-4208-8

12. Krause, D. J.; Kominek, J.; Opulente, D. A.; Shen, X.-X.; Zhou, X.; Langdon, Q. K.; DeVirgilio, J.; Hulfachor, A. B.; Kurtzman, C. P.; Rokas, A.; Hittinger, C. T. Proc. Natl. Acad. Sci. U. S. A. 2018, 115 , 11030-11035. doi:10.1073/pnas.1806268115

13. Smith, D. J.; Burnham, M. K. R.; Edwards, J.; Earl, A. J.; Turner, G. Bio/Technology 1990, 8, 39-41. doi:10.1038/nbt0190-39

14. Keller, N. P. Nat. Rev. Microbiol. 2019, 17, 167-180. doi:10.1038/s41579-018-0121-1

15. O'Donnell, K.; Cigelnik, E.; Casper, H. H. Fungal Genet. Biol. 1998, 23, 57-67. doi:10.1006/fgbi.1997.1018
16. Martin, F.; Kohler, A.; Murat, C.; Balestrini, R.; Coutinho, P. M.; Jaillon, O.; Montanini, B.; Morin, E.; Noel, B.; Percudani, R.; Porcel, B.; Rubini, A.; Amicucci, A.; Amselem, J.; Anthouard, V. Arcioni, S.; Artiguenave, F.; Aury, J.-M.; Ballario, P.; Bolchi, A.; Brenna, A.; Brun, A.; Buée, M.; Cantarel, B.; Chevalier, G.; Couloux, A.; Da Silva, C.; Denoeud, F.; Duplessis, S.; Ghignone, S.; Hilselberger, B.; lotti, M.; Marçais, B.; Mello, A.; Miranda, M.; Pacioni, G.; Quesneville, H.; Riccioni, C.; Ruotolo, R.; Splivallo, R.; Stocchi, V.; Tisserant, E.; Viscomi, A. R.; Zambonelli, A.; Zampieri, E.; Henrissat, B.; Lebrun, M.-H.; Paolocci, F.; Bonfante, P.; Ottonello, S.; Wincker, P. Nature 2010, 464, 1033-1038. doi:10.1038/nature08867

17. Karwehl, S.; Stadler, M. Exploitation of Fungal Biodiversity for Discovery of Novel Antibiotics. In How to Overcome the Antibiotic Crisis : Facts, Challenges, Technologies and Future Perspectives; Stadler, M.; Dersch, P., Eds.; Springer International Publishing: Cham, Switzerland, 2016; pp 303-338. doi:10.1007/82_2016_496

18. Spiteller, P. Chem. - Eur. J. 2008, 14, 9100-9110. doi:10.1002/chem.200800292

19. Zeng, R. S. L.; Niu, G.; Wen, Z.; Schuler, M. A.; Berenbaum, M. R. J. Chem. Ecol. 2006, 32, 1459-1471. doi:10.1007/s10886-006-9062-7

20. González-Osnaya, L.; Soriano, J. M.; Moltó, J. C.; Mañes, J. Food Addit. Contam. 2007, 24, 1268-1274. doi:10.1080/02652030701361556

21. Reiss, J. Chem.-Biol. Interact. 1975, 10, 339-342. doi:10.1016/0009-2797(75)90055-1

22. Cary, J. W.; Harris-Coward, P. Y.; Ehrlich, K. C.; Di Mavungu, J. D.; Malysheva, S. V.; De Saeger, S.; Dowd, P. F.; Shantappa, S.; Martens, S. L.; Calvo, A. M. Fungal Genet. Biol. 2014, 64, 25-35. doi:10.1016/j.fgb.2014.01.001

23. Zhao, Y.; Ding, J.; Yuan, W.; Huang, J.; Huang, W.; Wang, Y.; Zheng, W. Environ. Microbiol. 2017, 19, 3920-3929. doi:10.1111/1462-2920.13791

24. Xu, Y.; Vinas, M.; Alsarrag, A.; Su, L.; Pfohl, K.; Rohlfs, M.; Schäfer, W.; Chen, W.; Karlovsky, P. Nat. Commun. 2019, 10, 3579. doi:10.1038/s41467-019-11377-5

25. Eadie, M. J. Lancet Neurol. 2003, 2, 429-434. doi:10.1016/s1474-4422(03)00439-3

26. Tudzynski, P.; Correia, T.; Keller, U. Appl. Microbiol. Biotechnol. 2001, 57, 593-605. doi:10.1007/s002530100801

27. Tudzynski, P.; Scheffer, J. Mol. Plant Pathol. 2004, 5, 377-388. doi:10.1111/j.1364-3703.2004.00237.x

28. Schardl, C. L.; Panaccione, D. G.; Tudzynski, P. Ergot Alkaloids Biology and Molecular Biology. The Alkaloids: Chemistry and Biology; Academic Press, 2006; Vol. 63, pp 45-86. doi:10.1016/s1099-4831(06)63002-2

29. Radosa, S.; Ferling, I.; Sprague, J. L.; Westermann, M.; Hillmann, F. Environ. Microbiol. 2019, 21, 1809-1820. doi:10.1111/1462-2920.14588

30. Van Waeyenberghe, L.; Baré, J.; Pasmans, F.; Claeys, M.; Bert, W.; Haesebrouck, F.; Houf, K.; Martel, A. Environ. Microbiol. Rep. 2013, 5 , 819-824. doi:10.1111/1758-2229.12082

31. Brunke, S.; Mogavero, S.; Kasper, L.; Hube, B. Curr. Opin. Microbiol. 2016, 32, 89-95. doi:10.1016/j.mib.2016.05.010

32. Tosetti, N.; Croxatto, A.; Greub, G. Microb. Pathog. 2014, 77, 125-130. doi:10.1016/j.micpath.2014.07.009

33. Sanchez, J. F.; Somoza, A. D.; Keller, N. P.; Wang, C. C. C. Nat. Prod. Rep. 2012, 29, 351-371. doi:10.1039/c2np00084a

34. Show, P. L.; Oladele, K. O.; Siew, Q. Y.; Aziz Zakry, F. A.; Lan, J. C.-W.; Ling, T. C. Front. Life Sci. 2015, 8, 271-283. doi:10.1080/21553769.2015.1033653 
35. Stötefeld, L.; Scheu, S.; Rohlfs, M. Ecol. Entomol. 2012, 37, 323-329. doi:10.1111/j.1365-2311.2012.01373.x

36. Rohlfs, M. Fungal secondary metabolism in the light of animal-fungus interactions: from mechanism to ecological function. In Biosynthesis and Molecular Genetics of Fungal Secondary Metabolites; Zeilinger, S.; Martín, J. F.; García-Estrada, C., Eds.; Springer: New York, NY, USA, 2015; Vol. 3, pp 177-198. doi:10.1007/978-1-4939-2531-5_9

37. Künzler, M. PLoS Pathog. 2018, 14, e1007184. doi:10.1371/journal.ppat.1007184

38. Brakhage, A. A.; Langfelder, K. Annu. Rev. Microbiol. 2002, 56, 433-455. doi:10.1146/annurev.micro.56.012302.160625

39. Novohradská, S.; Ferling, I.; Hillmann, F. Front. Cell. Infect. Microbiol. 2017, 7, 497. doi:10.3389/fcimb.2017.00497

40. Latge, J.-P. Clin. Microbiol. Rev. 1999, 12, 310-350. doi:10.1128/cmr.12.2.310

41. Bignell, E.; Cairns, T. C.; Throckmorton, K.; Nierman, W. C.; Keller, N. P. Philos. Trans. R. Soc., B 2016, 371, 20160023. doi:10.1098/rstb.2016.0023

42. Frisvad, J. C.; Rank, C.; Nielsen, K. F.; Larsen, T. O. Med. Mycol. 2009, 47 (Suppl. 1), S53-S71. doi:10.1080/13693780802307720

43. Inglis, D. O.; Binkley, J.; Skrzypek, M. S.; Arnaud, M. B.; Cerqueira, G. C.; Shah, P.; Wymore, F.; Wortman, J. R.; Sherlock, G. BMC Microbiol. 2013, 13, 91. doi:10.1186/1471-2180-13-91

44. Lind, A. L.; Wisecaver, J. H.; Lameiras, C.; Wiemann, P.; Palmer, J. M.; Keller, N. P.; Rodrigues, F.; Goldman, G. H.; Rokas, A. PLoS Biol. 2017, 15, e2003583. doi:10.1371/journal.pbio.2003583

45. Heinekamp, T.; Thywißen, A.; Macheleidt, J.; Keller, S.; Valiante, V.; Brakhage, A. A. Front. Microbiol. 2013, 3, 440. doi:10.3389/fmicb.2012.00440

46. Gómez, B. L.; Nosanchuk, J. D. Curr. Opin. Infect. Dis. 2003, 16, 91-96. doi:10.1097/00001432-200304000-00005

47. Nguyen, K.-H.; Chollet-Krugler, M.; Gouault, N.; Tomasi, S. Nat. Prod. Rep. 2013, 30, 1490-1508. doi:10.1039/c3np70064j

48. Brakhage, A. A.; Liebmann, B. Med. Mycol. 2005, 43 (Suppl. 1), S75-S82. doi:10.1080/13693780400028967

49. Jahn, B.; Langfelder, K.; Schneider, U.; Schindel, C.; Brakhage, A. A. Cell. Microbiol. 2002, 4, 793-803. doi:10.1046/j.1462-5822.2002.00228.x

50. Ferling, I.; Dunn, J. D.; Ferling, A.; Soldati, T.; Hillmann, F. mBio 2020, 11. doi:10.1128/mbio.00862-20

51. Lim, F. Y.; Hou, Y.; Chen, Y.; Oh, J.-H.; Lee, I.; Bugni, T. S.; Keller, N. P. Appl. Environ. Microbiol. 2012, 78, 4117-4125. doi:10.1128/aem.07710-11

52. Berthier, E.; Lim, F. Y.; Deng, Q.; Guo, C.-J.; Kontoyiannis, D. P.; Wang, C. C. C.; Rindy, J.; Beebe, D. J.; Huttenlocher, A.; Keller, N. P. PLoS Pathog. 2013, 9, e1003289. doi:10.1371/journal.ppat.1003289

53. Throckmorton, K.; Lim, F. Y.; Kontoyiannis, D. P.; Zheng, W.; Keller, N. P. Environ. Microbiol. 2016, 18, 246-259. doi:10.1111/1462-2920.13007

54. Hissen, A. H. T.; Wan, A. N. C.; Warwas, M. L.; Pinto, L. J.; Moore, M. M. Infect. Immun. 2005, 73, 5493-5503. doi:10.1128/iai.73.9.5493-5503.2005

55. Schrettl, M.; Bignell, E.; Kragl, C.; Joechl, C.; Rogers, T.; Arst, H. N., Jr.; Haynes, K.; Haas, H. J. Exp. Med. 2004, 200 , 1213-1219. doi:10.1084/jem.20041242

56. Kato, N.; Suzuki, H.; Okumura, H.; Takahashi, S.; Osada, H. Biosci., Biotechnol., Biochem. 2013, 77, 1061-1067. doi:10.1271/bbb.130026
57. Ehlers, T.; Furness, S.; Robinson, T. P.; Zhong, H. A.; Goldsmith, D.; Aribser, J.; Bowen, J. P. Curr. Top. Med. Chem. 2016, 16, 1478-1488. doi:10.2174/1568026615666150915121204

58. van den Heever, J. P.; Thompson, T. S.; Curtis, J. M.; Ibrahim, A.; Pernal, S. F. J. Agric. Food Chem. 2014, 62, 2728-2737. doi:10.1021/jf4055374

59. Mendoza, Y.; Diaz-Cetti, S.; Ramallo, G.; Santos, E.; Porrini, M.; Invernizzi, C. J. Econ. Entomol. 2017, 110, 1-5. doi:10.1093/jee/tow228

60. Fallon, J. P.; Reeves, E. P.; Kavanagh, K. J. Med. Microbiol. 2010, 59, 625-633. doi:10.1099/jmm.0.018192-0

61. Fallon, J. P.; Reeves, E. P.; Kavanagh, K. Microbiology (Reading, U. K.) 2011, 157, 1481-1488. doi:10.1099/mic.0.043786-0

62. Guruceaga, X.; Ezpeleta, G.; Mayayo, E.; Sueiro-Olivares, M.; Abad-Diaz-De-Cerio, A.; Aguirre Urízar, J. M.; Liu, H. G.; Wiemann, P.; Bok, J. W.; Filler, S. G.; Keller, N. P.; Hernando, F. L.; Ramirez-Garcia, A.; Rementeria, A. Virulence 2018, 9, 1548-1561. doi:10.1080/21505594.2018.1526528

63. Pinheiro, E. A. A.; Carvalho, J. M.; dos Santos, D. C. P.; Feitosa, A. d. O.; Marinho, P. S. B.; Guilhon, G. M. S. P.; de Souza, A. D. L.; da Silva, F. M. A.; Marinho, A. M. d. R. Nat. Prod. Res. 2013, 27, 1633-1638. doi:10.1080/14786419.2012.750316

64. Ma, H.-Y.; Song, Y.-C.; Mao, Y.-Y.; Jiang, J.-H.; Tan, R.-X.; Luo, L. Planta Med. 2006, 72, 387-392. doi:10.1055/s-2005-916235

65. Li, Y.-X.; Himaya, S. W. A.; Dewapriya, P.; Zhang, C.; Kim, S.-K. Mar. Drugs 2013, 11, 5063-5086. doi:10.3390/md11125063

66. Panaccione, D. G.; Arnold, S. L. Sci. Rep. 2017, 7, 8930. doi:10.1038/s41598-017-09107-2

67. Du, R. H.; Li, E. G.; Cao, Y.; Song, Y. C.; Tan, R. X. Life Sci. 2011, 89 235-240. doi:10.1016/j.lfs.2011.06.015

68. Macheleidt, J.; Scherlach, K.; Neuwirth, T.; Schmidt-Heck, W.; Straßburger, M.; Spraker, J.; Baccile, J. A.; Schroeder, F. C.; Keller, N. P.; Hertweck, C.; Heinekamp, T.; Brakhage, A. A. Mol. Microbiol. 2015, 96, 148-162. doi:10.1111/mmi.12926

69. Lim, F. Y.; Ames, B.; Walsh, C. T.; Keller, N. P. Cell. Microbiol. 2014, 16, 1267-1283. doi:10.1111/cmi.12284

70. Garcia Silva, M.; Araçari Jacometti Cardoso Furtado, N.; Tallarico Pupo, M.; José Vieira Fonseca, M.; Said, S.; Alves da Silva Filho, A.; Kenupp Bastos, J. Microbiol. Res. 2004, 159, 317-322. doi:10.1016/j.micres.2004.06.003

71. Belofsky, G. N.; Anguera, M.; Jensen, P. R.; Fenical, W.; Köck, M. Chem. - Eur. J. 2000, 6, 1355-1360. doi:10.1002/(sici)1521-3765(20000417)6:8<1355::aid-chem1355>3.0. co;2-s

72. Li, X.-J.; Zhang, Q.; Zhang, A.-L.; Gao, J.-M. J. Agric. Food Chem. 2012, 60, 3424-3431. doi:10.1021/jf300146n

73. Baccile, J. A.; Spraker, J. E.; Le, H. H.; Brandenburger, E.; Gomez, C.; Bok, J. W.; Macheleidt, J.; Brakhage, A. A.; Hoffmeister, D.; Keller, N. P.; Schroeder, F. C. Nat. Chem. Biol. 2016, 12, 419-424. doi:10.1038/nchembio.2061

74. Khalid, S.; Baccile, J. A.; Spraker, J. E.; Tannous, J.; Imran, M.; Schroeder, F. C.; Keller, N. P. ACS Chem. Biol. 2018, 13, 171-179. doi:10.1021/acschembio.7b00731

75. González-Lobato, L.; Real, R.; Prieto, J. G.; Álvarez, A. I.; Merino, G. Eur. J. Pharmacol. 2010, 644, 41-48. doi:10.1016/j.ejphar.2010.07.016 
76. Lehner, S. M.; Atanasova, L.; Neumann, N. K. N.; Krska, R.; Lemmens, M.; Druzhinina, I. S.; Schuhmacher, R. Appl. Environ. Microbiol. 2013, 79, 18-31. doi:10.1128/aem.02339-12

77. Ali, H.; Ries, M. I.; Lankhorst, P. P.; van der Hoeven, R. A. M.; Schouten, O. L.; Noga, M.; Hankemeier, T.; van Peij, N. N. M. E.; Bovenberg, R. A. L.; Vreeken, R. J.; Driessen, A. J. M. PLoS One 2014, 9, e98212. doi:10.1371/journal.pone.0098212

78. Scharf, D. H.; Brakhage, A. A.; Mukherjee, P. K. Environ. Microbiol. 2016, 18, 1096-1109. doi:10.1111/1462-2920.13080

79. Yamada, A.; Kataoka, T.; Nagai, K. Immunol. Lett. 2000, 71, 27-32. doi:10.1016/s0165-2478(99)00155-8

80. Schlam, D.; Canton, J.; Carreño, M.; Kopinski, H.; Freeman, S. A.; Grinstein, S.; Fairn, G. D. mBio 2016, 7. doi:10.1128/mbio.02242-15

81. Gardiner, D. M.; Waring, P.; Howlett, B. J. Microbiology (Reading, U. K.) 2005, 151, 1021-1032. doi:10.1099/mic.0.27847-0

82. Hillmann, F.; Novohradská, S.; Mattern, D. J.; Forberger, T.; Heinekamp, T.; Westermann, M.; Winckler, T.; Brakhage, A. A. Environ. Microbiol. 2015, 17, 2858-2869. doi:10.1111/1462-2920.12808

83. Mitsuguchi, H.; Seshime, Y.; Fujii, I.; Shibuya, M.; Ebizuka, Y.; Kushiro, T. J. Am. Chem. Soc. 2009, 131, 6402-6411. doi:10.1021/ja8095976

84. Lodeiro, S.; Xiong, Q.; Wilson, W. K.; Ivanova, Y.; Smith, M. L.; May, G. S.; Matsuda, S. P. T. Org. Lett. 2009, 11, 1241-1244. doi:10.1021/ol802696a

85. Kimura, M.; Kushiro, T.; Shibuya, M.; Ebizuka, Y.; Abe, I. Biochem. Biophys. Res. Commun. 2010, 391, 899-902. doi:10.1016/j.bbrc.2009.11.160

86. Ganaha, M.; Yoshii, K.; Ōtsuki, Y.; Iguchi, M.; Okamoto, Y.; Iseki, K.; Ban, S.; Ishiyama, A.; Hokari, R.; Iwatsuki, M.; Otoguro, K.; Ōmura, S.; Hashimoto, T.; Noji, M.; Umeyama, A. Chem. Pharm. Bull. 2016, 64, 988-990. doi:10.1248/cpb.c16-00220

87. Amitani, R.; Taylor, G.; Elezis, E.-N.; Llewellyn-Jones, C.; Mitchell, J.; Kuze, F.; Cole, P. J.; Wilson, R. Infect. Immun. 1995, 63, 3266-3271. doi:10.1128/iai.63.9.3266-3271.1995

88. Kong, F.-D.; Huang, X.-L.; Ma, Q.-Y.; Xie, Q.-Y.; Wang, P.; Chen, P.-W.; Zhou, L.-M.; Yuan, J.-Z.; Dai, H.-F.; Luo, D.-Q.; Zhao, Y.-X. J. Nat. Prod. 2018, 81, 1869-1876. doi:10.1021/acs.jnatprod.8b00382

89. Yin, W.-B.; Baccile, J. A.; Bok, J. W.; Chen, Y.; Keller, N. P.; Schroeder, F. C. J. Am. Chem. Soc. 2013, 135, 2064-2067. doi:10.1021/ja311145n

90. Wiemann, P.; Lechner, B. E.; Baccile, J. A.; Velk, T. A.; Yin, W.-B.; Bok, J. W.; Pakala, S.; Losada, L.; Nierman, W. C.; Schroeder, F. C. Front. Microbiol. 2014, 5, 530. doi:10.3389/fmicb.2014.00530

91. König, C. C.; Scherlach, K.; Schroeckh, V.; Horn, F.; Nietzsche, S.; Brakhage, A. A.; Hertweck, C. ChemBioChem 2013, 14, 938-942. doi:10.1002/cbic.201300070

92. Chooi, Y.-H.; Fang, J.; Liu, H.; Filler, S. G.; Wang, P.; Tang, Y. Org. Lett. 2013, 15, 780-783. doi:10.1021/ol303435y

93. Andersen, M. R.; Nielsen, J. B.; Klitgaard, A.; Petersen, L. M.; Zachariasen, M.; Hansen, T. J.; Blicher, L. H.; Gotfredsen, C. H.; Larsen, T. O.; Nielsen, K. F.; Mortensen, U. H. Proc. Natl. Acad. Sci. U. S. A. 2013, 110, E99-E107. doi:10.1073/pnas.1205532110

94. Mehedi, M. A. U.; Molla, A. H.; Khondkar, P.; Sultana, S.; Islam, M. A.; Rashid, M. A.; Chowdhury, R. Asian J. Chem. 2010, 22, 2611-2614.
95. Wiemann, P.; Guo, C.-J.; Palmer, J. M.; Sekonyela, R.; Wang, C. C. C.; Keller, N. P. Proc. Natl. Acad. Sci. U. S. A. 2013, 110, 17065-17070. doi:10.1073/pnas.1313258110

96. Ishikawa, M.; Ninomiya, T.; Akabane, H.; Kushida, N.; Tsujiuchi, G.; Ohyama, M.; Gomi, S.; Shito, K.; Murata, T. Bioorg. Med. Chem. Lett. 2009, 19, 1457-1460. doi:10.1016/j.bmcl.2009.01.029

97. Maiya, S.; Grundmann, A.; Li, X.; Li, S.-M.; Turner, G. ChemBioChem 2007, 8, 1736-1743. doi:10.1002/cbic.200700202

98. Omura, S.; Tomoda, H.; Kim, Y. K.; Nishida, H. J. Antibiot. 1993, 46, 1168-1169. doi:10.7164/antibiotics.46.1168

99. Hu, J.; Furutani, A.; Yamamoto, K.; Oyama, K.; Mitomi, M.; Anzai, H. Biotechnol. Biotechnol. Equip. 2014, 28, 818-826. doi:10.1080/13102818.2014.960140

100.Goto, K.; Horikoshi, R.; Mitomi, M.; Oyama, K.; Hirose, T.; Sunazuka, T.; Ōmura, S. J. Antibiot. 2018, 71, 785-797. doi:10.1038/s41429-018-0064-9

101. VanMiddlesworth, F.; Dufresne, C.; Wincott, F. E.; Mosley, R. T.; Wilson, K. E. Tetrahedron Lett. 1992, 33, 297-300. doi:10.1016/s0040-4039(00)74115-3

102. VanMiddlesworth, F.; Giacobbe, R. A.; Lopez, M.; Garrity, G.; Bland, J. A.; Bartizal, K.; Fromtling, R. A.; Polishook, J.; Zweerink, M.; Edison, A. M. J. Antibiot. 1992, 45, 861-867. doi:10.7164/antibiotics.45.861

103. Rank, C. Mapping of secondary metabolism in biotechnologically important Aspergillus species. Ph.D. Thesis, Technical University of Denmark, Lyngby, Denmark, 2010.

104. Kobayashi, S.; Furuta, T.; Hayashi, T.; Nishijima, M.; Hanada, K. J. Am. Chem. Soc. 1998, 120, 908-919. doi:10.1021/ja9730829

105. Mattern, D. J.; Schoeler, H.; Weber, J.; Novohradská, S.; Kraibooj, K.; Dahse, H.-M.; Hillmann, F.; Valiante, V.; Figge, M. T.; Brakhage, A. A. Appl. Microbiol. Biotechnol. 2015, 99, 10151-10161. doi:10.1007/s00253-015-6898-1

106. Balan, J.; Ebringer, L.; Nemec, P.; Kováč, Š.; Dobias, J. J. Antibiot., Ser. A 1963, 16, 157-160.

107.Gauthier, T.; Wang, X.; Sifuentes Dos Santos, J.; Fysikopoulos, A.; Tadrist, S.; Canlet, C.; Artigot, M. P.; Loiseau, N.; Oswald, I. P.; Puel, O. PLoS One 2012, 7, e29906. doi:10.1371/journal.pone.0029906

108. Khoufache, K.; Puel, O.; Loiseau, N.; Delaforge, M.; Rivollet, D.; Coste, A.; Cordonnier, C.; Escudier, E.; Botterel, F.; Bretagne, S. BMC Microbiol. 2007, 7, No. 1. doi:10.1186/1471-2180-7-1

109. Gallagher, R. T.; Latch, G. C. M. Appl. Environ. Microbiol. 1977, 33, 730-731. doi:10.1128/aem.33.3.730-731.1977

110.Wang, F.; Fang, Y.; Zhu, T.; Zhang, M.; Lin, A.; Gu, Q.; Zhu, W. Tetrahedron 2008, 64, 7986-7991. doi:10.1016/j.tet.2008.06.013

111.Lim, F. Y.; Won, T. H.; Raffa, N.; Baccile, J. A.; Wisecaver, J.; Rokas, A.; Schroeder, F. C.; Keller, N. P. mBio 2018, 9. doi:10.1128/mbio.00785-18

112.Bok, J. W.; Chung, D.; Balajee, S. A.; Marr, K. A.; Andes, D.; Nielsen, K. F.; Frisvad, J. C.; Kirby, K. A.; Keller, N. P. Infect. Immun. 2006, 74, 6761-6768. doi:10.1128/iai.00780-06

113.Bell, M. R.; Johnson, J. R.; Wildi, B. S.; Woodward, R. B. J. Am. Chem. Soc. 1958, 80, 1001. doi:10.1021/ja01537a065

114.Bok, J. W.; Balajee, S. A.; Marr, K. A.; Andes, D.; Nielsen, K. F.; Frisvad, J. C.; Keller, N. P. Eukaryotic Cell 2005, 4, 1574-1582. doi:10.1128/ec.4.9.1574-1582.2005

115.Cramer, R. A., Jr.; Gamcsik, M. P.; Brooking, R. M.; Najvar, L. K.; Kirkpatrick, W. R.; Patterson, T. F.; Balibar, C. J.; Graybill, J. R.; Perfect, J. R.; Abraham, S. N.; Steinbach, W. J. Eukaryotic Cell 2006, 5, 972-980. doi:10.1128/ec.00049-06 
116.Kupfahl, C.; Heinekamp, T.; Geginat, G.; Ruppert, T.; Härtl, A.; Hof, H.; Brakhage, A. A. Mol. Microbiol. 2006, 62, 292-302. doi:10.1111/j.1365-2958.2006.05373.x

117.Scharf, D. H.; Remme, N.; Heinekamp, T.; Hortschansky, P.; Brakhage, A. A.; Hertweck, C. J. Am. Chem. Soc. 2010, 132, 10136-10141. doi:10.1021/ja103262m

118.Schrettl, M.; Carberry, S.; Kavanagh, K.; Haas, H.; Jones, G. W.; O'Brien, J.; Nolan, A.; Stephens, J.; Fenelon, O.; Doyle, S. PLoS Pathog. 2010, 6, e1000952. doi:10.1371/journal.ppat.1000952

119.McDonagh, A.; Fedorova, N. D.; Crabtree, J.; Yu, Y.; Kim, S.; Chen, D.; Loss, O.; Cairns, T.; Goldman, G.; Armstrong-James, D.; Haynes, K.; Haas, H.; Schrettl, M.; May, G.; Nierman, W. C.; Bignell, E. PLoS Pathog. 2008, 4, e1000154. doi:10.1371/journal.ppat.1000154

120.Sugui, J. A.; Kim, H. S.; Zarember, K. A.; Chang, Y. C.; Gallin, J. I.; Nierman, W. C.; Kwon-Chung, K. J. PLoS One 2008, 3, e2655. doi:10.1371/journal.pone.0002655

121.Sugui, J. A.; Pardo, J.; Chang, Y. C.; Zarember, K. A.; Nardone, G.; Galvez, E. M.; Müllbacher, A.; Gallin, J. I.; Simon, M. M.; Kwon-Chung, K. J. Eukaryotic Cell 2007, 6, 1562-1569. doi:10.1128/ec.00141-07

122. Vargas, W. A.; Mukherjee, P. K.; Laughlin, D.; Wiest, A.; Moran-Diez, M. E.; Kenerley, C. M. Microbiology (Reading, U. K.) 2014, 160, 2319-2330. doi:10.1099/mic.0.079210-0

123. Coyle, C. M.; Kenaley, S. C.; Rittenour, W. R.; Panaccione, D. G. Mycologia 2007, 99, 804-811. doi:10.1080/15572536.2007.11832512

124.Perrin, R. M.; Fedorova, N. D.; Bok, J. W.; Cramer, R. A.; Wortman, J. R.; Kim, H. S.; Nierman, W. C.; Keller, N. P. PLoS Pathog. 2007, 3, e50. doi:10.1371/journal.ppat.0030050

125. Twumasi-Boateng, K.; Yu, Y.; Chen, D.; Gravelat, F. N.; Nierman, W. C.; Sheppard, D. C. Eukaryotic Cell 2009, 8, 104-115. doi:10.1128/ec.00265-08

126. Upadhyay, S.; Torres, G.; Lin, X. Eukaryotic Cell 2013, 12, 1641-1652. doi:10.1128/ec.00217-13

127. Hanson, F. R.; Eble, T. E. J. Bacteriol. 1949, 58, 527-529. doi:10.1128/jb.58.4.527-529.1949

128.Lin, H.-C.; Chooi, Y.-H.; Dhingra, S.; Xu, W.; Calvo, A. M.; Tang, Y. J. Am. Chem. Soc. 2013, 135, 4616-4619. doi:10.1021/ja312503y

129.Sin, N.; Meng, L.; Wang, M. Q. W.; Wen, J. J.; Bornmann, W. G.; Crews, C. M. Proc. Natl. Acad. Sci. U. S. A. 1997, 94, 6099-6103. doi:10.1073/pnas.94.12.6099

130. Mauriz, J. L.; Martín-Renedo, J.; García-Palomo, A.; Tuñón, M. J.; González-Gallego, J. Curr. Drug Targets 2010, 11, 1439-1457. doi:10.2174/1389450111009011439

131. Vetro, J. A.; Dummitt, B.; Chang, Y.-H. Methionine Aminopeptidase. In Aminopeptidases in Biology and Disease; Hooper, N. M.; Lendeckel, U., Eds.; Proteases in Biology and Disease, Vol. 2; Springer: Boston, MA, USA, 2004; pp 17-44. doi:10.1007/978-1-4419-8869-0_2

132.Conrad, T.; Kniemeyer, O.; Henkel, S. G.; Krüger, T.; Mattern, D. J.; Valiante, V.; Guthke, R.; Jacobsen, I. D.; Brakhage, A. A.; Vlaic, S.; Linde, J. BMC Syst. Biol. 2018, 12, 88. doi:10.1186/s12918-018-0620-8

133. Netzker, T.; Fischer, J.; Weber, J.; Mattern, D. J.; König, C. C.; Valiante, V.; Schroeckh, V.; Brakhage, A. A. Front. Microbiol. 2015, 6, 299. doi:10.3389/fmicb.2015.00299

134.Guruceaga, X.; Perez-Cuesta, U.; Abad-Diaz de Cerio, A.; Gonzalez, O.; Alonso, R. M.; Hernando, F. L.; Ramirez-Garcia, A.; Rementeria, A. Toxins 2019, 12, 7. doi:10.3390/toxins 12010007
135.Molina, J.-M.; Tourneur, M.; Sarfati, C.; Chevret, S.; de Gouvello, A.; Gobert, J.-G.; Balkan, S.; Derouin, F. N. Engl. J. Med. 2002, 346, 1963-1969. doi:10.1056/nejmoa012924

136. Keller, N.; Bok, J.; Chung, D.; Perrin, R. M.; Keats Shwab, E. Med. Mycol. 2006, 44 (Suppl. 1), S83-S85. doi:10.1080/13693780600835773

137.Romsdahl, J.; Wang, C. C. C. Med. Chem. Commun. 2019, 10 , 840-866. doi:10.1039/c9md00054b

138. Wang, J.; Sheppard, G. S.; Lou, P.; Kawai, M.; BaMaung, N.; Erickson, S. A.; Tucker-Garcia, L.; Park, C.; Bouska, J.; Wang, Y.-C. Cancer Res. 2003, 63, 7861-7869.

139. Yamaoka, M.; Yamamoto, T.; Ikeyama, S.; Sudo, K.; Fujita, T. Cancer Res. 1993, 53, 5233-5236.

140. Tucker, L. A.; Zhang, Q.; Sheppard, G. S.; Lou, P.; Jiang, F.; McKeegan, E.; Lesniewski, R.; Davidsen, S. K.; Bell, R. L.; Wang, J. Oncogene 2008, 27, 3967-3976. doi:10.1038/onc.2008.14

141.McCowen, M. C.; Callender, M. E.; Lawlis, J. F., Jr. Science 1951, 113, 202-203. doi:10.1126/science.113.2930.202

142. Arico-Muendel, C.; Centrella, P. A.; Contonio, B. D.; Morgan, B. A.; O'Donovan, G.; Paradise, C. L.; Skinner, S. R.; Sluboski, B.; Svendsen, J. L.; White, K. F.; Debnath, A.; Gut, J.; Wilson, N.; McKerrow, J. H.; DeRisi, J. L.; Rosenthal, P. J.; Chiang, P. K. Bioorg. Med. Chem. Lett. 2009, 19, 5128-5131. doi:10.1016/j.bmcl.2009.07.029

143. Eisenman, H. C.; Casadevall, A. Appl. Microbiol. Biotechnol. 2012, 93, 931-940. doi:10.1007/s00253-011-3777-2

144.Cecchini, M. M.; Reale, S.; Manini, P.; d'Ischia, M.; De Angelis, F. Chem. - Eur. J. 2017, 23, 8092-8098. doi:10.1002/chem.201701951

145. Tsai, H.-F.; Washburn, R. G.; Chang, Y. C.; Kwon-Chung, K. J. Mol. Microbiol. 1997, 26, 175-183. doi:10.1046/j.1365-2958.1997.5681921.x

146. Schmaler-Ripcke, J.; Sugareva, V.; Gebhardt, P.; Winkler, R.; Kniemeyer, O.; Heinekamp, T.; Brakhage, A. A. Appl. Environ. Microbiol. 2009, 75, 493-503. doi:10.1128/aem.02077-08

147.Perez-Cuesta, U.; Aparicio-Fernandez, L.; Guruceaga, X.; Martin-Souto, L.; Abad-Diaz-de-Cerio, A.; Antoran, A.; Buldain, I.; Hernando, F. L.; Ramirez-Garcia, A.; Rementeria, A. Int. Microbiol. 2020, 23, 55-63. doi:10.1007/s10123-019-00078-0

148. Tsai, H.-F.; Wheeler, M. H.; Chang, Y. C.; Kwon-Chung, K. J. J. Bacteriol. 1999, 181, 6469-6477. doi:10.1128/jb.181.20.6469-6477.1999

149. Fujii, I.; Yasuoka, Y.; Tsai, H.-F.; Chang, Y. C.; Kwon-Chung, K. J.; Ebizuka, Y. J. Biol. Chem. 2004, 279, 44613-44620. doi:10.1074/jbc.m406758200

150. Langfelder, K.; Jahn, B.; Gehringer, H.; Schmidt, A.; Wanner, G.; Brakhage, A. A. Med. Microbiol. Immunol. 1998, 187, 79-89. doi:10.1007/s004300050077

151.Tsai, H.-F.; Fujii, I.; Watanabe, A.; Wheeler, M. H.; Chang, Y. C.; Yasuoka, Y.; Ebizuka, Y.; Kwon-Chung, K. J. J. Biol. Chem. 2001, 276, 29292-29298. doi:10.1074/jbc.m101998200

152.Sugareva, V.; Härtl, A.; Brock, M.; Hübner, K.; Rohde, M.; Heinekamp, T.; Brakhage, A. A. Arch. Microbiol. 2006, 186, 345-355. doi:10.1007/s00203-006-0144-2

153. Manini, P.; Bietti, M.; Galeotti, M.; Salamone, M.; Lanzalunga, O.; Cecchini, M. M.; Reale, S.; Crescenzi, O.; Napolitano, A.; De Angelis, F.; Barone, V.; d'Ischia, M. ACS Omega 2018, 3, 3918-3927. doi:10.1021/acsomega.8b00155 
154.Chai, L. Y. A.; Netea, M. G.; Sugui, J.; Vonk, A. G.; van de Sande, W. W. J.; Warris, A.; Kwon-Chung, K. J.; Kullberg, B. J. Immunobiology 2010, 215, 915-920. doi:10.1016/j.imbio.2009.10.002

155. Thywißen, A.; Heinekamp, T.; Dahse, H.-M.; Schmaler-Ripcke, J.; Nietsche, S.; Zipfel, P. F.; Brakhage, A. A. Front. Microbiol. 2011, 2, 96. doi:10.3389/fmicb.2011.00096

156.Stappers, M. H. T.; Clark, A. E.; Aimanianda, V.; Bidula, S.; Reid, D. M.; Asamaphan, P.; Hardison, S. E.; Dambuza, I. M.; Valsecchi, I.; Kerscher, B.; Plato, A.; Wallace, C. A.; Yuecel, R.; Hebecker, B.; da Glória Teixeira Sousa, M.; Cunha, C.; Liu, Y.; Feizi, T.; Brakhage, A. A.; Kwon-Chung, K. J.; Gow, N. A. R.; Zanda, M.; Piras, M.; Zanato, C.; Jaeger, M.; Netea, M. G.; van de Veerdonk, F. L.; Lacerda, J. F.; Campos, A.; Carvalho, A.; Willment, J. A.; Latgé, J.-P.; Brown, G. D. Nature 2018, 555, 382-386. doi:10.1038/nature25974

157.Wong, S. S. W.; Rani, M.; Dodagatta-Marri, E.; Ibrahim-Granet, O.; Kishore, U.; Bayry, J.; Latgé, J.-P.; Sahu, A.; Madan, T.; Aimanianda, V. J. Biol. Chem. 2018, 293, 4901-4912. doi:10.1074/jbc.m117.815852

158. Kozlovskii, A. G.; Zhelifonova, V. P.; Antipova, T. V. Appl. Biochem. Microbiol. 2013, 49, 1-10. doi:10.1134/s0003683813010092

159. Robinson, S. L.; Panaccione, D. G. Toxins 2015, 7, 201-218. doi:10.3390/toxins7010201

160.Li, S.-M. J. Antibiot. 2011, 64, 45-49. doi:10.1038/ja.2010.128

161.Grundmann, A.; Li, S.-M. Microbiology (Reading, U. K.) 2005, 151, 2199-2207. doi:10.1099/mic.0.27962-0

162. Yamazaki, M.; Fujimoto, H.; Kawasaki, T. Chem. Pharm. Bull. 1980, 28, 245-254. doi:10.1248/cpb.28.245

163.Cui, C.-B.; Kakeya, H.; Osada, H. Tetrahedron 1997, 53, 59-72. doi:10.1016/s0040-4020(96)00978-7

164. Rabindran, S. K.; Ross, D. D.; Doyle, L. A.; Yang, W.; Greenberger, L. M. Cancer Res. 2000, 60, 47-50.

165.Chain, E.; Florey, H.; Jennings, M.; Williams, T. Br. J. Exp. Pathol. 1943, 24, 108.

166. Rank, C.; Larsen, T. O.; Frisvad, J. C. Functional systems biology of Aspergillus. In Aspergillus: molecular biology and genomics; Machida, M.; Gomi, K., Eds.; Caister Academic Press: Norfolk, UK, 2010; pp 173-198.

167.Tamiya, H.; Ochiai, E.; Kikuchi, K.; Yahiro, M.; Toyotome, T.; Watanabe, A.; Yaguchi, T.; Kamei, K. J. Infect. Chemother. 2015, 21 , 385-391. doi:10.1016/j.jiac.2015.01.005

168. Cole, R. J.; Jarvis, B. B.; Schweikert, M. A. Handbook of secondary fungal metabolites; Elsevier, 2003.

169.Lv, J.-M.; Hu, D.; Gao, H.; Kushiro, T.; Awakawa, T.; Chen, G.-D.; Wang, C.-X.; Abe, I.; Yao, X.-S. Nat. Commun. 2017, 8, 1644. doi:10.1038/s41467-017-01813-9

170.Tomoda, H.; Nishida, H.; Kim, Y. K.; Obata, R.; Sunazuka, T.; Omura, S.; Bordner, J.; Guadliana, M.; Dormer, P. G.; Smith, A. B., III. J. Am. Chem. Soc. 1994, 116, 12097-12098. doi:10.1021/ja00105a078

171.Kim, Y. K.; Tomoda, H.; Nishida, H.; Sunazuka, T.; Obata, R.; Omura, S. J. Antibiot. 1994, 47, 154-162. doi:10.7164/antibiotics.47.154

172. Itoh, T.; Tokunaga, K.; Matsuda, Y.; Fujii, I.; Abe, I.; Ebizuka, Y.; Kushiro, T. Nat. Chem. 2010, 2, 858-864. doi:10.1038/nchem.764

173.Das, A.; Davis, M. A.; Tomoda, H.; Ômura, S.; Rudel, L. L. J. Biol. Chem. 2008, 283, 10453-10460. doi:10.1074/jbc.m709460200
174.Ohshiro, T.; Matsuda, D.; Sakai, K.; Degirolamo, C.; Yagyu, H.; Rudel, L. L.; Ōmura, S.; Ishibashi, S.; Tomoda, H. Arterioscler., Thromb., Vasc. Biol. 2011, 31, 1108-1115. doi:10.1161/atvbaha.111.223552

175. Raffa, N.; Keller, N. P. PLoS Pathog. 2019, 15, e1007606. doi:10.1371/journal.ppat.1007606

\section{License and Terms}

This is an Open Access article under the terms of the Creative Commons Attribution License (https://creativecommons.org/licenses/by/4.0). Please note that the reuse, redistribution and reproduction in particular requires that the author(s) and source are credited and that individual graphics may be subject to special legal provisions.

The license is subject to the Beilstein Journal of Organic Chemistry terms and conditions: (https://www.beilstein-journals.org/bjoc/terms)

The definitive version of this article is the electronic one which can be found at: https://doi.org/10.3762/bjoc.17.124 